\title{
6-17 Yaş Arası Ankara Çocuk ve Adölesanlarında Büyüme Durumunun Değerlendirilmesi
}

* Sorumlu Yazar / Corresponding Author: Başak KOCA ÖZER Ankara Üniversitesi Dil ve Tarih - Coğrafya Fakültesi Antropoloji Bölümü, Fizik Antropoloji Anabilim Dalı 06100 Sıhhiye, Ankara / TÜRKIYE E-posta: bkozer@ankara.edu.tr

\section{Başak Koca Özer ${ }^{1 *} \odot$, Ayşegül Özdemir ${ }^{2} \odot$, Sibel Önal ${ }^{3} \odot$, Cansev Meşe Yavuz ${ }^{4} \odot$}

\author{
'Prof. Dr. | Ankara Üniversitesi, Dil ve Tarih - Coğrafya Fakültesi, Antropoloji Bölümü, Ankara / TÜRKIYE \\ ${ }^{2}$ Arş. Gör. | Ankara Üniversitesi, Dil ve Tarih - Coğrafya Fakültesi, Antropoloji Bölümü, Ankara / TÜRKiYE \\ ${ }^{3}$ Arş. Gör. Dr. | Ankara Üniversitesi, Dil ve Tarih - Coğrafya Fakültesi, Antropoloji Bölümü, Ankara / TÜRKiYE \\ ${ }^{4}$ Dr. Öğr. Üyesi | Van Yüzüncü Yıl, Fen - Edebiyat Fakültesi, Antropoloji Bölümü, Van / TÜRKiYE
}

Alındı/Received: 22 Nisan / April 2020 Düzeltildi/Revised: 22 Haziran / June 2020 Yayımlandı/Published: 29 Haziran / June 2020

Öz

Çalışmanın amacı Ankara ilinde yaşayan okul çocuklarını büyüme ve gelişme açısından değerlendirmek ve güncel antropometrik değerleri belirleyerek seküler değişim açısından karşılaştırma olanağı sağlamaktır. Kesitsel olarak yürütülen araştırmada, 6-17 yaş arası 1484 (761 erkek, 723 kı) çocuk ve adölesandan uluslararası antropometrik protokollere uygun olarak boy ve ağırlık ölçülmüş, LMS metoduyla düzeltilmiş persentil tabloları oluşturulmuştur. Beden Kitle Endisi (BKE) hesaplanmış ve Dünya Sağlık Örgütü'nün (DSÖ) değerlerine göre malnütrisyon ve obezite durumu değerlendirilmiştir. Boy ve ağırlık değerleri tüm yaş gruplarında erkek çocuklarda daha yüksek bulunmuştur. 14-17 yaşları arasında boy uzunluğu büyüme atılımı ile ilişkili olarak cinsiyetler arasında anlamlı bulunmuştur $(p<0,001)$. BKE özellikle erkek çocuk ve adölesanlarda alt ve üst persentiller arasında büyük farklılık sergilemektedir. Çalışma sonuçları erkek çocuklarının çevresel şartlardan daha fazla etkilendiklerini, obezite ile malnütrisyon yüzdelerinin ise kızlardan daha yüksek olduğunu göstermektedir. Çocuk ve adölesanlarda büyüme takibinin yapılması için lokal referans büyüme tablolarının oluşturulması ve aynı zamanda da halk sağlığı düzeyinin belirlenebilmesi için popülasyon düzeyinde antropometrik çalışmaların sürekliliğinin sağlanması gerektiği kanısındayız.

Anahtar Sözcükler: Antropometri, boy, ağırlık, beden kitle endisi, Ankara

\section{Giriş}

Büyüme ve gelişme dinamik bir süreçtir. Genetik ve çevresel koşulların baskısı altında şekillenirken, anne karnından başlayarak, bebeklik, erken çocukluk, juvenil ve adölesan dönemlerden erişkinlik dönemine kadar farklı tempolarda sürmektedir (Malina ve Bouchard, 1991; Hermanussen, 2013). Fiziksel büyümenin takibinde boy ve ağırllk değerleri büyüme ve gelișme çalışmalarında sıklıkla kullanılırken, persentil eğirileri ve z skorları olarak adlandırdığımı standart sapma skorları (SD) yardımılla grup içi ve gruplararası
Evaluation of Growth Status in Ankara School Children and Adolescents Aged 6-17 Years

Abstract

The aim of the study is to evaluate the growth and development of school children and adolescents living in Ankara, to determine the up-to-date anthropometric values and to compare them in terms of secular change. The study was carried out cross-sectionally on 1484 (761 boys, 723 girls) children and adolescents aged 6-17 years that measured in accordance with international anthropometric protocols, and smoothed percentiles were constructed using the LMS method. Body Mass Index (BMI) was calculated, malnutrition and obesity were evaluated the World Health Organization (WHO) cut-offs. Height and weight were found to be higher for boys for all age groups. Sexual dimorphism was significant between 14-17 ages due to the growth spurt $(p<0.001)$. $B M I$ difference was higher between lower and higher percentiles particularly for boys. Boys were found to be more eco-sensitive, and malnutrition and obesity prevalence were bigher. It is important to conduct population based anthropometric studies to construct local reference growth tables, in order to follow up growth in children and adolescents as well as to determine public health status.

Key Words: Anthropometry, height, weight, body mass index, Ankara

karșilaş̧ırma olanağı sağlanmaktadır (Neyzi vd., 2008; Cole, 2013).

Boy uzunluğu genel sağltk durumunun bir göstergesidir ve disiplinlerarası çalışmalarda kullanılan önemli bir değişkendir (Hermanussen, 2013). Tarihsel süreçte boy uzunluğunun savaş ve kıtllk gibi negatif koşulların etkisine bağlı olarak olumsuz etkilendiği, sosyo-ekonomik gelişmelere bağlı olarak da pozitif etkilendiği belirtilmektedir (Koca Özer, 2007). Büyüme ve gelişme sürecinde ağırllk takibi, malnütrisyon ve obezite de özellikle son dönemde oldukça önemli 
bir çalıșma konusu haline gelmiştir. Gelișmekte olan ülkelerde malnütrisyon ciddi bir halk sağllğ̆ sorunudur. Obezite ise vücuda alınan enerjinin harcanan enerjiden fazla olmas1 sebebiyle normalden fazla kilo alımının ortaya çıkması olarak tanımlanmaktadır. Obezitenin ortaya çıkışında fazla kalori alımı ve fiziksel aktivite azlığının etkisibulunmaktadır. Beden Kitle Endisi (BKE), özellikle son yillarda tüm dünyada ciddi bir sorun olarak görülen obezite ve malnütrisyonun değerlendirilmesinde sıklıkla kullanılmaktadır. Dünya Sağlık Örgütü (DSÖ) ve Hastalik Kontrol Merkezi (Centers for Disease Control$C D C$ ) ve Uluslararası Obezite Görev Gücü (International Obesity Task. Force-IOTF) tarafindan yaş ve cinsiyete göre oluşturulan kesim değerleri de obezite ve malnütrisyonun değerlendirilmesinde kullanılmaktadır (Önal vd., 2016).

$\mathrm{Bu}$ çalışmanın amacı Ankara ilinde yaşayan 6-17 yaş çocuk ve adölesanların boy ve ağırlık ölçümleri kullanılarak büyüme durumlarının tespiti ve BKE'den yararlanılarak malnütrisyon ve Obezite gibi beslenme durumlarının Dünya Sağlık Örgütü değerleriyle karşılaştırmaktır.

\section{Gereç ve Yöntem}

Çalışmamız kesitsel olarak Ankara ilinde yaşayan 6-17 yaş arası toplam 1484 (761 erkek, 723 kız) çocuk ve adölesan, farklı sosyo-ekonomik düzeyi temsil eden ve çalışmaya katılmay1 gönüllü olarak kabul eden bireyler üzerinde gerçekleştirilmiştir. Aile onamı ve bireysel gönüllülük esas alınmış ve örnekleme ait kişisel bilgilerin gizliliği göz önünde bulundurulmuştur. Çalışma kapsamında Ankara Üniversitesi Etik Kurulu'nun (02.07.2015 tarihli 1227 sayllı) kararı ile etik onay ve ayrıca Ankara İl Millî Eğitim Müdürlüğ̈u’nden gerekli yasal izinler alınmıştır.

Antropometrik ölçüler, International Biological Programme'1n (Weiner ve Lourie, 1969) öngördüğü teknikler doğrultusunda standart protokollere uygun olarak alınmıştır. Boy Martin tipi antropometre (mm'ye duyarlı) ile ağırlık ise Tanita SC 330 S vücut analiz cihazı (100 grama duyarlı) ile ölçülmüştür. Beden Kitle Endisi Ağırlık $(\mathrm{kg}) /$ Boy uzunluğu $\left(\mathrm{m}^{2}\right)$ hesaplanmıştır. Çalışmamı kapsamında elde edilen boy uzunluğu ve ağırlık değerleri (<-3SD, <-2SD, Normal, >+2SD, $>+3 \mathrm{SD})$ ile çocukların BKE'leri (<-3SD, <-2SD, Normal, $>+1 \mathrm{SD},>+2 \mathrm{SD},>+3 \mathrm{SD})$ DSÖ z skoru kesim noktaları dikkate alınarak hesaplanmıştır (DSÖ, 2020). Yaşa ve cinsiyete özgü boy, ağırlık ve BKE değerlerine ait persentiller LMS metoduna (Cole, 1990; Cole ve Green, 1992) göre hesaplanmıştır. LMS metodu Box-Cox transformasyonuyla yaşa bağlı çarpıklığı gidermek için büyüme tablolarının hazırlanması için DSÖ tarafindan da kullanılan bir metottur (L: çarpıklık katsayısı; M: medyan; S: varyasyon katsayısı).

$$
\begin{gathered}
\mathrm{C} 100 \alpha=\mathrm{M}(1+\mathrm{LSz} \alpha) 1 / \mathrm{L} ; \mathrm{L}=0 \\
\mathrm{zi}=(\mathrm{Y} / \mathrm{M}) \mathrm{L}-1 / \mathrm{LS} ; \mathrm{L}=0
\end{gathered}
$$

Boy uzunluğu ve ağırlık verilerinin yaşa ve cinsiyete özgü analizi z skorları (SDS) yardımılla gerçekleştirilmiştir. Veriler SPSS 21.0 programında, Kolmogorov-Simirnov, Mann Whitney U ve bağımsız örneklem $t$ testleri ile değerlendirilmiştir.

\section{Bulgular}

Örneklemin yaşa ve cinsiyete göre birey sayıları, boy uzunluğu, seçili persentil ve LMS değerleri Tablo 1'de sunulmuştur. Boy uzunluğu yaş ile beraber artış göstermektedir ve tüm yaşlarda erkeklerde daha yüksektir. Boy uzunluğu arasındaki farkın büyüme atılımı ile ilişkili olduğu ve 14-17 yaşları arasındaki erkek ve kız çocuklarda arasında istatistiksel açıdan anlamlı olduğu anlaşılmıştır $(p<0,001)$.

Ağırlık ortalamaları tüm yaşlarda erkeklerde kızlara oranla daha yüksektir. Erkek çocuklarda özellikle büyüme atağ1 ile beraber ortaya çıkan ikincil cinsiyet karakterlerinin ve kas oranındaki artışa bağlı olarak ağırlık değerinin 15-17 yaş arasında ise her iki cinsiyet arasında istatistikî açıdan anlamlı farklılık gösterdiği görülmüştür $(\mathrm{p}<0,001)$ (Tablo 2).

BKE değerlerine bakıldı̆̆ında, 11 yaşında cinsiyetler arasında istatistiksel olarak anlamlılık olduğu saptanmıştır $(p<0,05)$ (Tablo 3). Persentil değerlerine bakıldığında, erkek çocuklarda 3. ve 97. persentiller arasında oldukça belirgin farklıllğın olduğu görülmektedir.

Örneklemin boy uzunluk $\mathrm{z}$ skorları DSÖ referanslarına göre yaştan bağımsız olarak değerlendirildiğine \%0,2'si çok kısa boylu (<-3SD), $\% 1,5$ 'i kisa boylu (<-2SD), \%2,5'i uzun boylu (>+2SD) ve $\% 0,3$ 'ü ise çok uzun boylu $(>+3 \mathrm{SD})$ bulunmuştur. Yaşa göre boy uzunluğuna bakıldığında çok kısa boyluluk oranı (<-3SD) en fazla 14 yaşındaki erkeklerde görülürken, bu oran kızlarda 6 yaşındaki çocuklarda belirlenmiştir. Yaşına göre uzun boyluluk $(>+2 S D)$ ve çok uzun boyluluk $(>+3 \mathrm{SD})$ ise erkeklerde kızlara göre daha yaygın olarak görülmektedir (Tablo 4).

Cinsiyetlere göre ağırlık z skorları DSÖ referans kesim noktalarına göre değerlendirildiğinde, örneklemin $\% 0,2$ 'si çok zayıf (<-3SD), \%2'si zayıf (<-2SD), \%8,9'u fazla kilolu $(>+2$ SD) ve $\% 4,8$ 'i ise obez $(>+3$ SD) olarak bulunmuştur (Tablo 5). Yaşa göre ağırlık z skorlan DSÖ referans tablolarında 10 yaşa kadar verildiğinden, çalışma örneklemi ile 6-10 yaş arası karşılaştırma sonuçları değerlendirilmiş ve çok düşük ağırlıklı (<-3SD) olanların yalnızca 8 yaşındaki erkeklerde görüldüğü belirlenmiştir. Yaşa göre zayıf olma durumu $(<-2 S D)$ ise neredeyse tüm yaşlarda görülmektedir. Yaşa göre fazla kiloluluk $(>+2 S D)$ genel olarak erkeklerde kızlara göre daha yüksek bulunmuştur.

DSÖ kesim noktalarına göre oluşturulan cinsiyetlere göre BKE z skorlarının dağılımı Tablo 6'da gösterilmiştir. Çocukların \%0,7'si çok düşük kilolu (<3SD), \%2,2'si düşük kiloludur (<-2SD). Fazla kilolu 


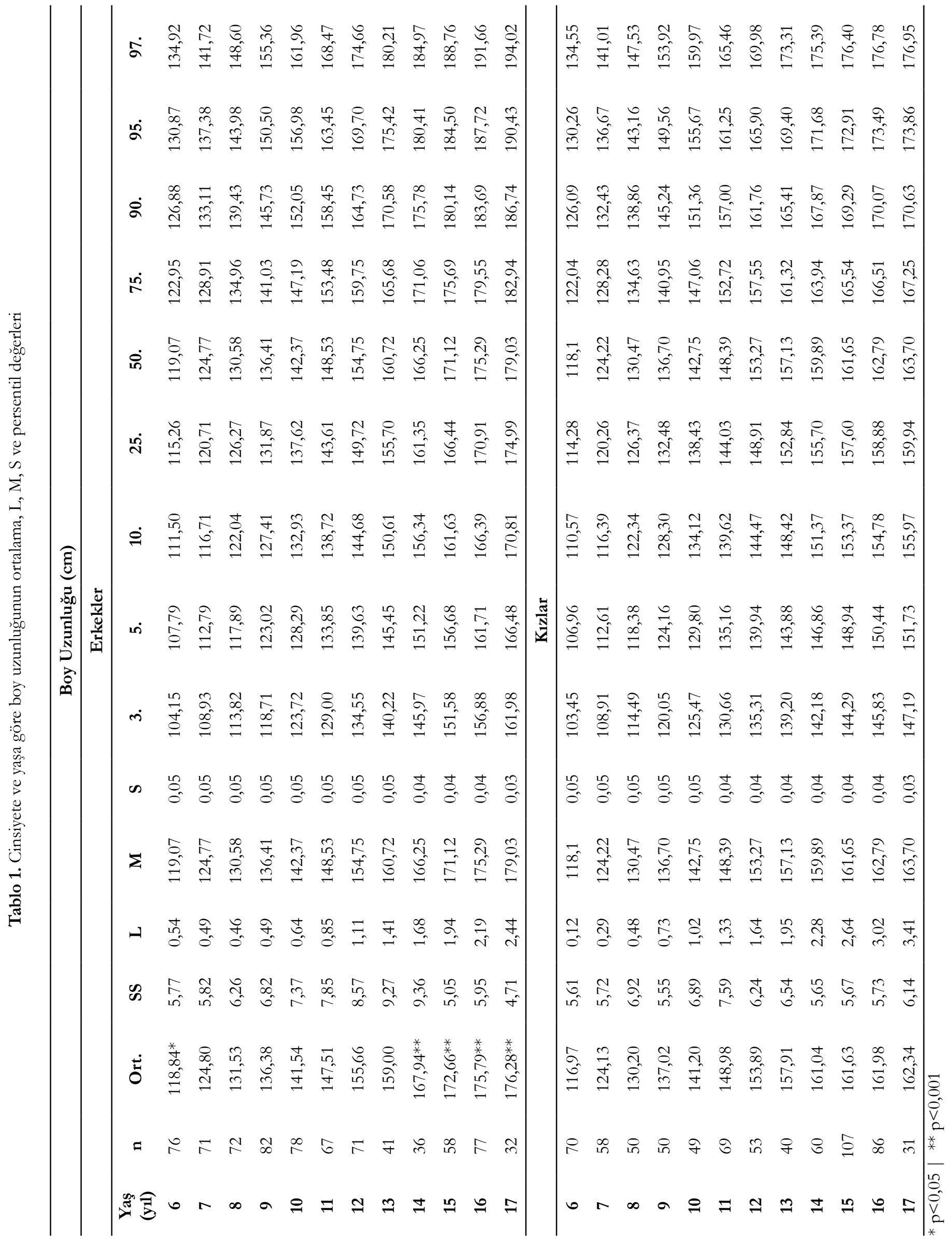




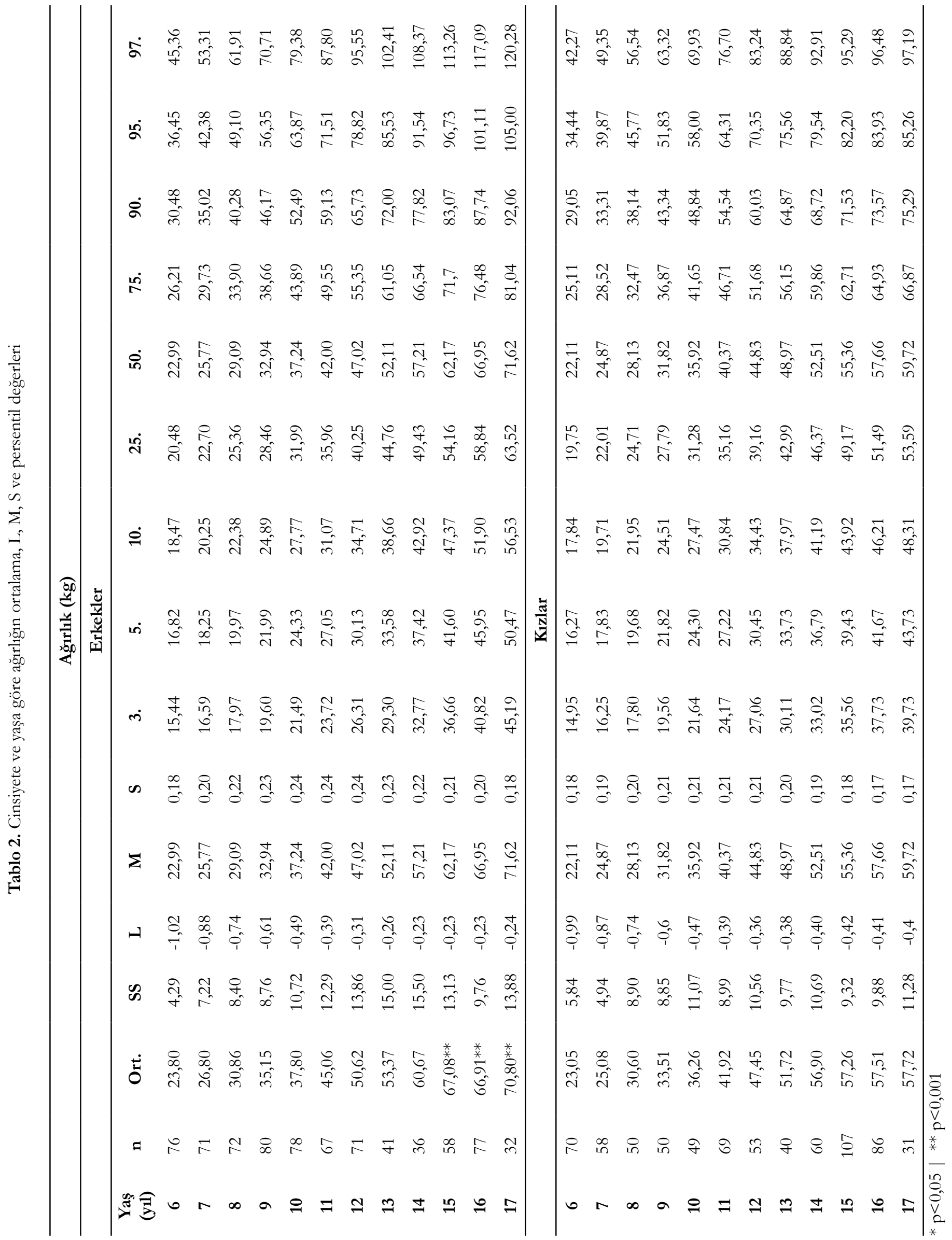




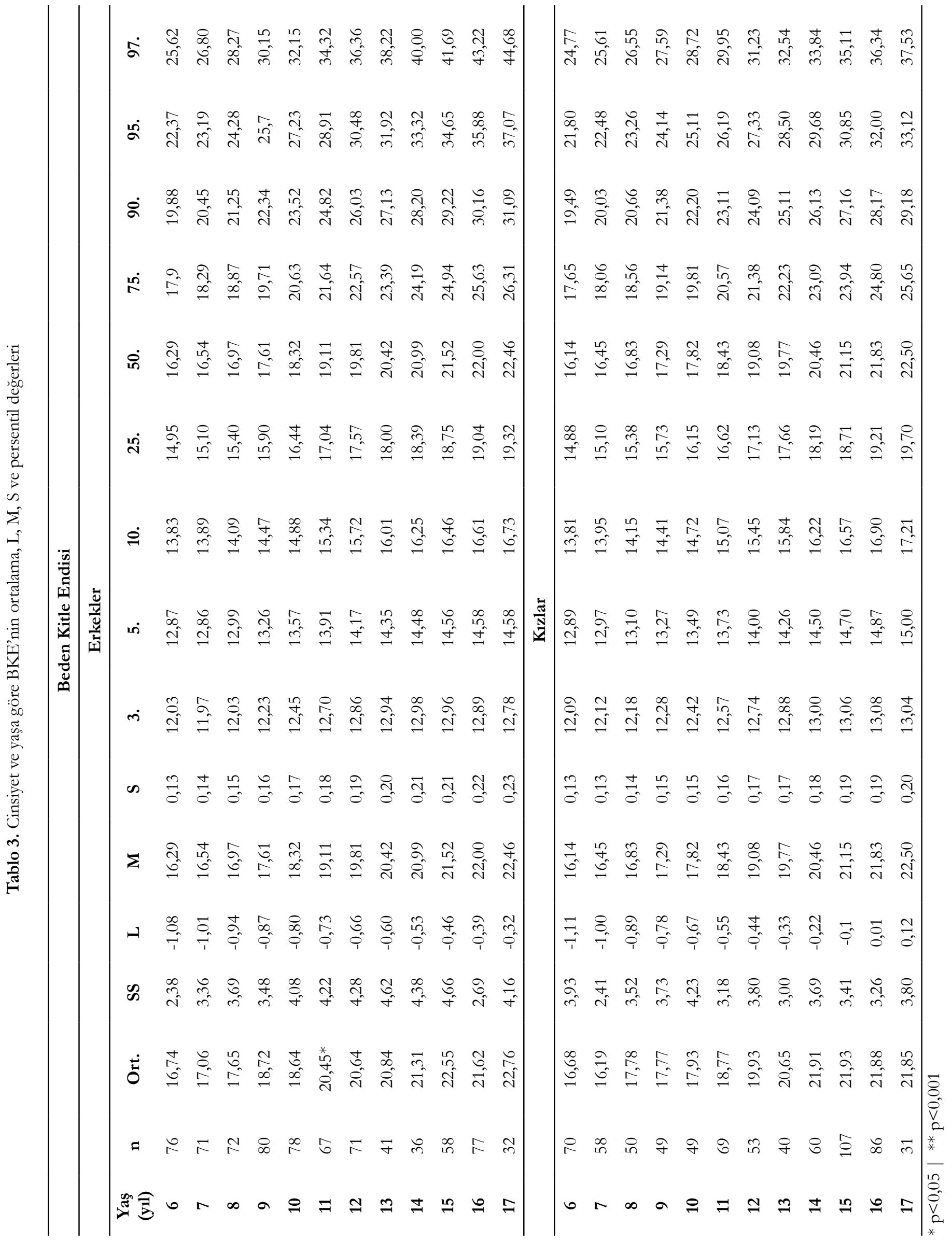


Koca Özer vd.|Antropoloji (39) (2020)

Tablo 4. Cinsiyetlere ve yaşlara göre boy uzunluğu z skorlarının DSÖ referanslarına göre dağılımı

\begin{tabular}{|c|c|c|c|c|c|c|c|c|c|c|}
\hline \multicolumn{11}{|c|}{ Erkekler } \\
\hline \multirow{2}{*}{ Yaş (yıl) } & \multicolumn{2}{|c|}{$<-3 S D$} & \multicolumn{2}{|c|}{$<-2 S D$} & \multicolumn{2}{|c|}{ Normal } & \multicolumn{2}{|c|}{$>+2 \mathrm{SD}$} & \multicolumn{2}{|c|}{$>+3 \mathrm{SD}$} \\
\hline & $\mathbf{n}$ & $\%$ & $\mathrm{n}$ & $\%$ & $\mathbf{n}$ & $\%$ & $\mathbf{n}$ & $\%$ & $\mathbf{n}$ & $\%$ \\
\hline 6 & 1 & 1,3 & - & - & 72 & 94,8 & 3 & 3,9 & - & - \\
\hline 7 & - & - & 1 & 1,4 & 68 & 95,8 & 2 & 2,8 & - & - \\
\hline 8 & - & - & - & - & 69 & 95,9 & 3 & 4,2 & - & - \\
\hline 9 & - & - & - & - & 79 & 96,3 & 1 & 1,2 & 2 & 2,4 \\
\hline 10 & - & - & 2 & 2,5 & 73 & 92,4 & 3 & 3,8 & 1 & 1,3 \\
\hline 11 & - & - & 1 & 1,5 & 63 & 94,0 & 3 & 4,5 & - & - \\
\hline 12 & - & - & 1 & 1,4 & 64 & 90,1 & 5 & 7,0 & 1 & 1,4 \\
\hline 13 & - & - & 3 & 7,3 & 35 & 85,4 & 3 & 7,3 & - & - \\
\hline 14 & 1 & 2,8 & 1 & 2,8 & 32 & 88,9 & 2 & 5,6 & - & - \\
\hline 15 & - & - & - & - & 57 & 98,3 & - & - & 1 & 1,7 \\
\hline 16 & - & - & - & - & 77 & 100 & - & - & - & - \\
\hline 17 & - & - & - & - & 31 & 96,8 & 1 & 3,2 & - & - \\
\hline Toplam & 2 & 0,3 & 9 & 1,2 & 720 & 94,6 & 26 & 3,4 & 4 & 0,5 \\
\hline \multicolumn{11}{|c|}{ K1zlar } \\
\hline \multirow{2}{*}{ Yaş (yıl) } & \multicolumn{2}{|c|}{$<-3 S D$} & \multicolumn{2}{|c|}{$<-2 S D$} & \multicolumn{2}{|c|}{ Normal } & \multicolumn{2}{|c|}{$>+2 \mathrm{SD}$} & \multicolumn{2}{|c|}{$>+3 \mathrm{SD}$} \\
\hline & $\mathbf{n}$ & $\%$ & $\mathrm{n}$ & $\%$ & $\mathrm{n}$ & $\%$ & $\mathbf{n}$ & $\%$ & $\mathbf{n}$ & $\%$ \\
\hline 6 & 1 & 1,4 & - & - & 67 & 97,1 & 1 & 1,4 & - & - \\
\hline 7 & - & - & - & - & 57 & 98,2 & 1 & 1,7 & - & - \\
\hline 8 & - & - & 2 & 4,0 & 45 & 90,0 & 2 & 4,0 & 1 & 2,0 \\
\hline 9 & - & - & - & - & 48 & 96,0 & 1 & 2,0 & - & - \\
\hline 10 & - & - & 2 & 4,1 & 46 & 93,8 & 1 & 2,0 & - & - \\
\hline 11 & - & - & 2 & 2,9 & 63 & 91,3 & 4 & 5,8 & - & - \\
\hline 12 & - & - & 2 & 3,8 & 51 & 96,2 & - & - & - & - \\
\hline 13 & - & - & 1 & 2,5 & 38 & 95,0 & 1 & 2,5 & - & - \\
\hline 14 & - & - & - & - & 60 & 100 & - & - & - & - \\
\hline 15 & - & - & 2 & 1,9 & 105 & 98,1 & - & - & - & - \\
\hline 16 & - & - & 1 & 1,2 & 85 & 98,9 & - & - & - & - \\
\hline 17 & - & - & 1 & 3,2 & 30 & 96,8 & - & - & - & - \\
\hline Toplam & 1 & 0,1 & 13 & 1,8 & 695 & 96,1 & 11 & 1,5 & 1 & 0,1 \\
\hline
\end{tabular}

$(>+1 \mathrm{SD}) \quad$ olan çocuklar \% 19 oranında, obezite ise $(>+2$ SD) $\% 11$ oranındadır. Çocukların \%2,7'si ise morbid obezdir. Çok düşük kiloluluğun erkeklerde en yüksek oranla 15 yaşında, kızlarda ise 10 yaşında olduğu görülmektedir. Düşük kiloluluk oranları ise erkeklerde en yüksek 14 yaşında, kızlarda 12 yaşında görüldüğü saptanmıştır. Fazla kiloluluk $(>+1 \mathrm{SD})$ ve obezite (+2SD) oranlarının erkeklerde kızlara göre daha yüksek olduğu görülmektedir. Morbid obezite $(>+3 S D)$ oranlarının erkeklerde 7 yaşta, kızlarda ise 8 yaşında görüldüğü belirlenmiştir.

\section{Tartışma}

Büyüme ve gelişmenin takibi özellikle gelişmekte olan ülkelerde çocuk sağlığının değerlendirilebilmesi açısından önem taşımaktadır. Boy uzunluğu ve ağırlık ölçümleri büyümenin takibinde sıklıkla kullanılan antropometrik ölçümler arasındadır (Gökçay vd., 2008). DSÖ ve CDC tarafindan oluşturulan referans persentil değerleri büyüme ve gelişmenin takibinde gerek dünyada gerekse ülkemizde kullanılmaktadır. Bu referans değerleri uygulama ve karşılaştırma açısından ülkemiz araştırmacıları için fikir verici olsa da ülkemiz çocuk ve gençlerine özgü referans değerlerinin oluşturulması da önem taşımaktadır (Öztürk vd., 2011). Her toplum kendine özgü beden yap1sı ve genetik özellikleri barındırmaktadır. Bu nedenle farklı yaşam koşullarına sahip bir başka topumun büyüme ve gelişme normlarını ülkemiz çocuklarına uygulandığında yanılgıya düşülebilir. Bu bağlamda Neyzi ve arkadaşları ile Öztürk ve arkadaşları tarafindan yapılan büyüme ve gelişme çalısmalarında elde edilen referans değerleri ülkemiz çocuklarının büyüme durumlarının belirlenebilmesi açısından önem taşımaktadır (Neyzi vd., 2008; Öztürk 
Koca Özer vd.|Antropoloji (39) (2020)

Tablo 5. Cinsiyetlere ve yaşlara göre ağırlık z skorlarının DSÖ referanslarına göre dağılımı

\begin{tabular}{|c|c|c|c|c|c|c|c|c|c|c|}
\hline \multicolumn{11}{|c|}{ Erkekler } \\
\hline \multirow{2}{*}{ Yaş (y1l) } & \multicolumn{2}{|c|}{$<-3 S D$} & \multicolumn{2}{|c|}{$<-2 \mathrm{SD}$} & \multicolumn{2}{|c|}{ Normal } & \multicolumn{2}{|c|}{$>+2 \mathrm{SD}$} & \multicolumn{2}{|c|}{$>+3 \mathrm{SD}$} \\
\hline & $\mathrm{n}$ & $\%$ & $\mathrm{n}$ & $\%$ & $\mathbf{n}$ & $\%$ & $\mathrm{n}$ & $\%$ & $\mathrm{n}$ & $\%$ \\
\hline 6 & - & - & 1 & 1,3 & 66 & 86,8 & 5 & 6,6 & 4 & 5,3 \\
\hline 7 & - & - & 2 & 2,8 & 61 & 86,0 & 4 & 5,6 & 4 & 5,6 \\
\hline 8 & 1 & 1,4 & 2 & 2,8 & 53 & 73,6 & 11 & 15,3 & 5 & 6,9 \\
\hline 9 & - & - & 1 & 1,3 & 65 & 81,3 & 10 & 12,5 & 4 & 5,0 \\
\hline 10 & - & - & 1 & 14,3 & 6 & 85,7 & - & - & - & - \\
\hline Toplam & 1 & 0,3 & 7 & 2,3 & 251 & 82 & 30 & 9,8 & 17 & 5,6 \\
\hline \multicolumn{11}{|c|}{ Kizlar } \\
\hline \multirow{2}{*}{ Yaş (y1l) } & \multicolumn{2}{|c|}{$<-3 S D$} & \multicolumn{2}{|c|}{$<-2 S D$} & \multicolumn{2}{|c|}{ Normal } & \multicolumn{2}{|c|}{$>+2 \mathrm{SD}$} & \multicolumn{2}{|c|}{$>+3 \mathrm{SD}$} \\
\hline & $\mathbf{n}$ & $\%$ & $\mathbf{n}$ & $\%$ & $\mathbf{n}$ & $\%$ & $\mathbf{n}$ & $\%$ & $\mathrm{n}$ & $\%$ \\
\hline 6 & - & - & 1 & 1,4 & 63 & 90,1 & 4 & 5,7 & 2 & 2,9 \\
\hline 7 & - & - & 1 & 1,7 & 52 & 89,6 & 4 & 6,9 & 1 & 1,7 \\
\hline 8 & - & - & - & - & 43 & 86,0 & 2 & 4,0 & 5 & 10,0 \\
\hline 9 & - & - & 1 & 2,0 & 42 & 82,3 & 7 & 13,7 & 1 & 2,0 \\
\hline 10 & - & - & 1 & 12,5 & 6 & 75,0 & 1 & 12,5 & - & - \\
\hline Toplam & - & - & 4 & 1,7 & 204 & 86,8 & 18 & 7,7 & 9 & 3,8 \\
\hline
\end{tabular}

vd., 2011). Bununla birlikte büyüme ve gelişme normları gelişmekte olan ülkelerde kısa zaman aralıklarında değişiklik gösterebildiği için referans değerlerinin belli periyotlarla yenilenmesi gerekmektedir (Fredriks vd., 2003). Son yıllarda ülkemizde yapılmış büyüme ve gelişme çalışmalarına bakıldığında pek çok araştırmacının farklı illerdeki çocukların büyüme durumlarının değerlendirilebilmesine yönelik antropometrik ölçümler yardımı ile yapmış olduğu fiziksel büyüme çalışmaları göze çarpmaktadır (Neyzi vd., 2013).

Yaşa göre kısa boylu olma durumunun, uzun vadeli tekrarlayan enfeksiyon ve yetersiz besin alımından kaynaklandığ1 bilinmektedir. Çalışmamızdan elde edilen boy değerlerimizin önceki y1llarda ülkemizde antropometrik ölçüler kullanılarak yapılan fiziki büyüme ve gelişme çalışmalarında elde edilen sonuçlara göre daha yüksek olduğu anlaşılmıştır (Bostanc1, 1954; Neyzi vd., 1978; Saatçioğlu, 1988; Duyar, 1993; Pala vd., 2002). Geçtiğimiz yüzyll içerisinde boy uzunluğu değerlerinde genellikle pozitif yönde seküler değissim olduğu dikkat çekmektedir. Ülkemizde yapılan büyüme gelişme çalışmalarından ilki sayılabilecek olan ve Kansu (1939) tarafindan yapılan çalışma sonuçlarından elde edilen veriler incelendiğinde boy uzunluğunun geçtiğimiz yüzyıl içerisinde belirgin oranda artış gösterdiği görülmektedir. Boy uzunluğu ve ağırlık gibi antropometrik değişkenler

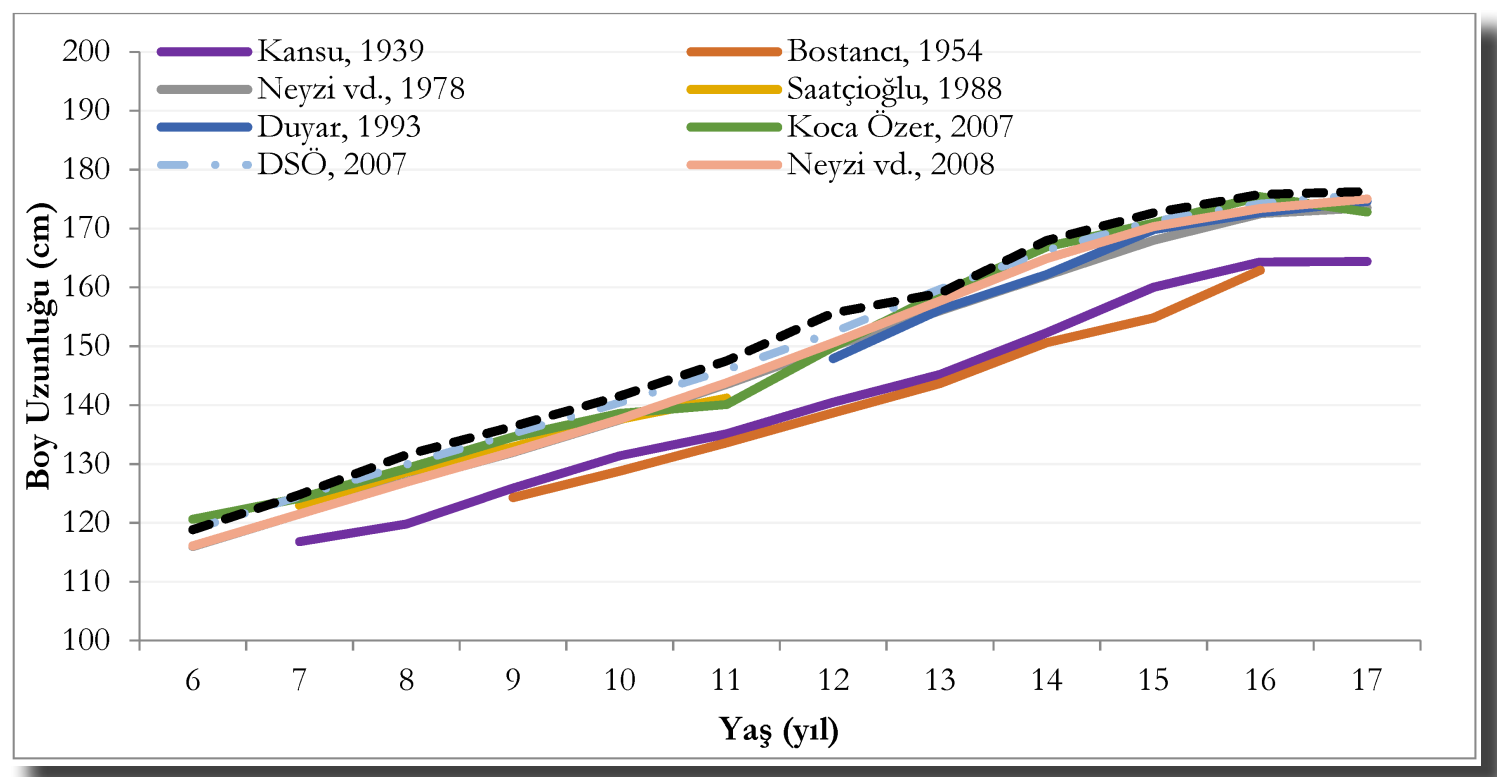

Grafik 1. Erkek çocuklarında yaşlara göre boy uzunluğunun yıllara göre değişimi 
Koca Özer vd.|Antropoloji (39) (2020)

Tablo 6. Cinsiyete ve yaşa göre BKE z skorlarının DSÖ referanslarına göre dağglımı

\begin{tabular}{|c|c|c|c|c|c|c|c|c|c|c|c|c|}
\hline \multicolumn{13}{|c|}{ Erkekler } \\
\hline \multirow{2}{*}{ Yaş (y1l) } & \multicolumn{2}{|c|}{$<-3 S D$} & \multicolumn{2}{|c|}{$<-2 S D$} & \multicolumn{2}{|c|}{ Normal } & \multicolumn{2}{|c|}{$>+1 S D$} & \multicolumn{2}{|c|}{$>+2 \mathrm{SD}$} & \multicolumn{2}{|c|}{$>+3 S D$} \\
\hline & $\mathrm{n}$ & $\%$ & $\mathrm{n}$ & $\%$ & $\mathrm{n}$ & $\%$ & $\mathrm{n}$ & $\%$ & $\mathrm{n}$ & $\%$ & $\mathrm{n}$ & $\%$ \\
\hline 6 & - & - & - & - & 46 & 62,2 & 14 & 18,9 & 8 & 10,8 & 6 & 8,1 \\
\hline 7 & - & - & 2 & 2,8 & 45 & 63,4 & 11 & 15,5 & 6 & 8,5 & 7 & 9,9 \\
\hline 8 & 1 & 1,4 & 2 & 2,8 & 40 & 56,4 & 11 & 15,5 & 13 & 18,3 & 4 & 5,6 \\
\hline 9 & 1 & 1,3 & - & - & 41 & 51,3 & 15 & 18,8 & 18 & 22,5 & 5 & 6,3 \\
\hline 10 & 1 & 1,3 & 3 & 3,8 & 42 & 53,2 & 18 & 22,8 & 12 & 15,2 & 3 & 3,8 \\
\hline 11 & - & - & 1 & 1,5 & 34 & 50,8 & 11 & 16,4 & 18 & 26,9 & 3 & 4,5 \\
\hline 12 & 1 & 1,4 & 1 & 1,4 & 35 & 49,3 & 19 & 26,8 & 13 & 18,3 & 2 & 2,8 \\
\hline 13 & - & - & 3 & 7,3 & 22 & 53,7 & 7 & 17,1 & 8 & 19,5 & 1 & 2,4 \\
\hline 14 & - & - & 4 & 11,1 & 17 & 47,2 & 11 & 30,6 & 4 & 11,1 & - & - \\
\hline 15 & 1 & 1,8 & 1 & 1,8 & 38 & 66,6 & 7 & 12,3 & 8 & 14,0 & 2 & 3,5 \\
\hline 16 & - & - & 2 & 2,6 & 62 & 80,5 & 11 & 14,3 & 2 & 2,6 & - & - \\
\hline 17 & - & - & 2 & 6,5 & 21 & 67,8 & 6 & 19,4 & 1 & 3,2 & 1 & 3,2 \\
\hline Toplam & 5 & 0,7 & 21 & 2,8 & 443 & 58,7 & 141 & 18,7 & 111 & 14,7 & 34 & 4,5 \\
\hline \multicolumn{13}{|c|}{ Kızlar } \\
\hline \multirow{2}{*}{ Yaş (y1l) } & \multicolumn{2}{|c|}{$<-3 S D$} & \multicolumn{2}{|c|}{$<-2 S D$} & \multicolumn{2}{|c|}{ Normal } & \multicolumn{2}{|c|}{$>+1 \mathrm{SD}$} & \multicolumn{2}{|c|}{$>+2 \mathrm{SD}$} & \multicolumn{2}{|c|}{$>+3 S D$} \\
\hline & $\mathrm{n}$ & $\%$ & $\mathrm{n}$ & $\%$ & $\mathrm{n}$ & $\%$ & $\mathrm{n}$ & $\%$ & $\mathrm{n}$ & $\%$ & $\mathrm{n}$ & $\%$ \\
\hline 6 & - & - & 1 & 1,4 & 46 & 66,7 & 15 & 21,7 & 5 & 7,2 & 2 & 2,9 \\
\hline 7 & - & - & - & - & 45 & 77,5 & 8 & 13,8 & 3 & 5,2 & 2 & 3,4 \\
\hline 8 & - & - & - & - & 33 & 66,0 & 10 & 20,0 & 5 & 10,0 & 2 & 4,0 \\
\hline 9 & 2 & 3,9 & - & - & 30 & 58,8 & 11 & 21,6 & 8 & 15,7 & - & - \\
\hline 10 & 2 & 4,1 & 3 & 6,1 & 30 & 61,2 & 7 & 14,3 & 7 & 14,3 & - & - \\
\hline 11 & 1 & 1,4 & 2 & 2,9 & 48 & 69,6 & 13 & 18,8 & 5 & 7,2 & - & - \\
\hline 12 & - & - & 4 & 7,5 & 33 & 62,2 & 11 & 20,8 & 5 & 9,4 & - & - \\
\hline 13 & - & - & - & - & 32 & 78,0 & 6 & 15,0 & 2 & 5,0 & - & - \\
\hline 14 & - & - & - & - & 42 & 70,0 & 14 & 23,3 & 4 & 6,7 & - & - \\
\hline 15 & - & - & - & - & 82 & 76,6 & 21 & 19,6 & 4 & 3,7 & - & - \\
\hline 16 & - & - & 1 & 1,2 & 67 & 77,9 & 16 & 18,6 & 2 & 2,3 & - & - \\
\hline 17 & - & - & 1 & 3,2 & 21 & 67,8 & 8 & 25,8 & 1 & 3,2 & - & - \\
\hline Toplam & 5 & 0,7 & 12 & 1,7 & 509 & 70,4 & 140 & 19,4 & 51 & 7,1 & 6 & 0,8 \\
\hline
\end{tabular}

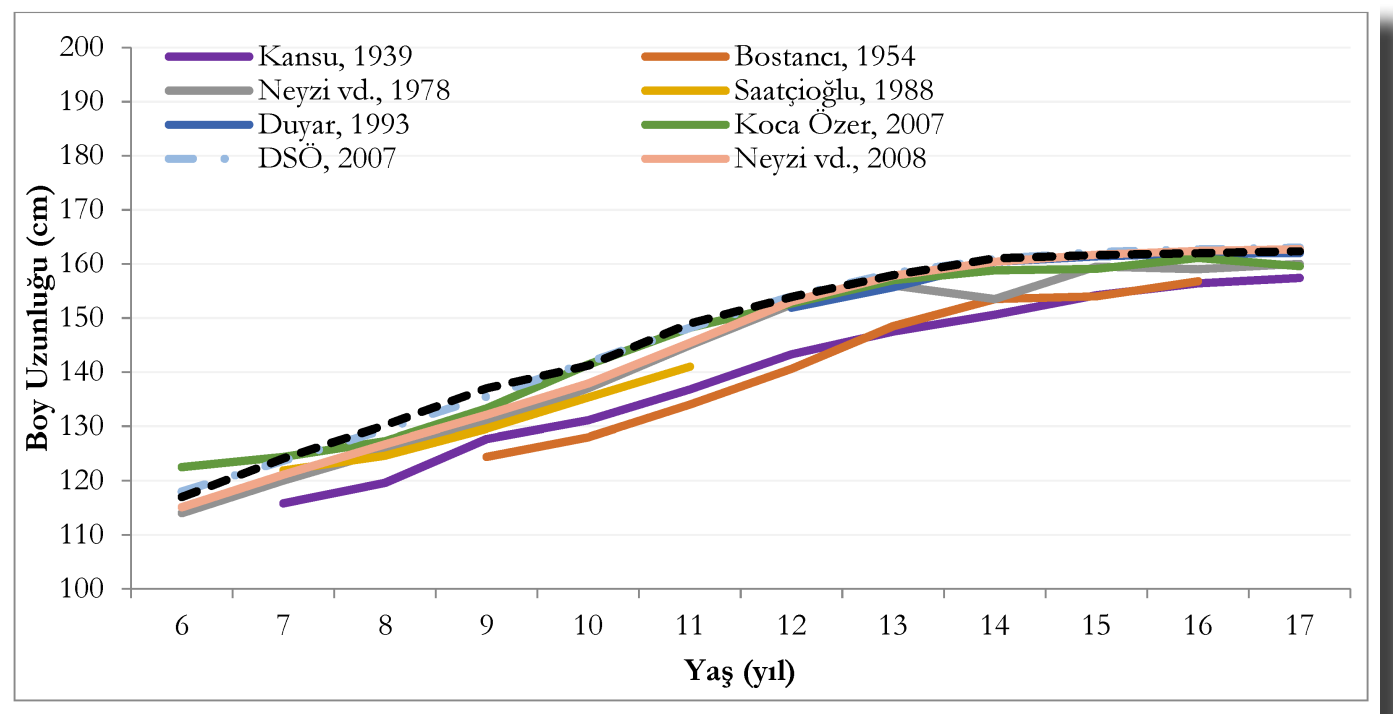

Grafik 2. Kız çocuklarında yaşlara göre boy uzunluğunun yıllara göre değişimi 
ülkenin değişken koşulları ile bağlantılı olduğundan kısa süreler içerisinde pozitif ya da negatif değişikliklerin olması beklenen bir sonuçtur. Koca Özer (2007) ve Neyzi ve arkadaşları (2008) tarafindan yapilan çalışmalar ile çalışma sonuçlarımız karşılaştırıldığında boy uzunluğunun kısa dönemler içinde gösterdiği değișiklikler görülmektedir. DSÖ (2007), değerleri ile çalışma değerlerimiz karşılaştırıldığında boy uzunluğu ortalama değerlerimizin DSÖ verileri ile benzer olduğu görülmektedir (Grafik 1 ve 2).

Ülkemizde yapılmış olan, Türkiye Beslenme ve Sağlık Araştırması (TBSA, 2014) verilerine göre 6-18 yaş arası çocuk ve adölesanlarda bodurluk oranı $\% 6,8$ olarak saptanmış ve yaşla beraber bu oranın azaldığ 1 belirtilmiştir. On iki Avrupa ülkesinde yaşayan 6-9 yaş arasındaki 168,832 çocuk üzerine yapılan çalışmada, DSÖ referanslarına göre, çok kısa boyluluk ve çok zayıflık oranı \%2,5'in altında belirlenmiștir (Wijnhoven vd., 2014). CDC tarafindan 11 yaşındaki 8317 çocuk ile yapılan çalışmada, 9 Avrupa ülkesindeki kısa boyluluk oranı en fazla Portekizli kız çocuklarda \%5,6, erkek çocuklarında ise \%6,2 olarak bulunmuştur. Hollanda ise kısa boyluluk oranının en düşük olduğu ülke olarak belirlenmiştir (Yngve vd., 2007). Çalışmamız sonuçlarına göre 11 yaşındaki erkek çocuklarda kısa boyluluk oranı \%1,5 iken kızlarda aynı yaşta kısa boylu bireyin olmadığ1 görülmüştür.

Özellikle son yıllarda önemli bir halk sağlı̆̆1 sorunu olarak karşımıza çıkan obezitenin yanı sıra yaşa göre düşük ağırlıklı olma durumu da dikkatle izlenmelidir. Malnütrisyonun yüzdelik değerler açısından fazla kilolu olma durumuyla benzer bir örüntü izlediği belirtilmektedir (TBSA, 2014; TOÇBİ, 2011). Boya göre düşük ağırlıklı olma durumu, erken çocukluk döneminde mortalitenin güçlü bir göstergesidir. $\mathrm{Bu}$ durum hastalık veya yetersiz beslenme sonucu olarak ortaya çıkmaktadır. Çocukluk döneminde beslenmeye bağlı malnütrisyon ve fazla kilolu olma durumu birçok

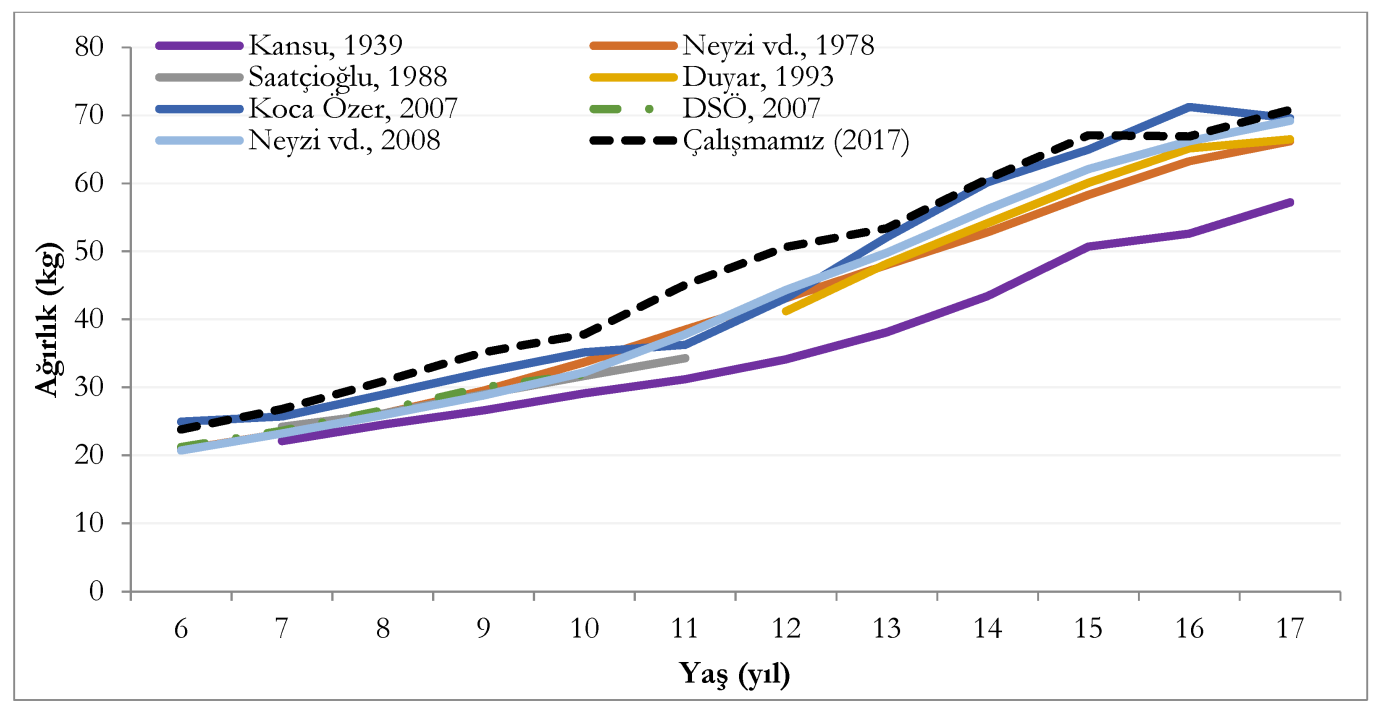

Grafik 3. Erkek çocuklarında yaşlara göre ağırlığın yıllara göre değişimi

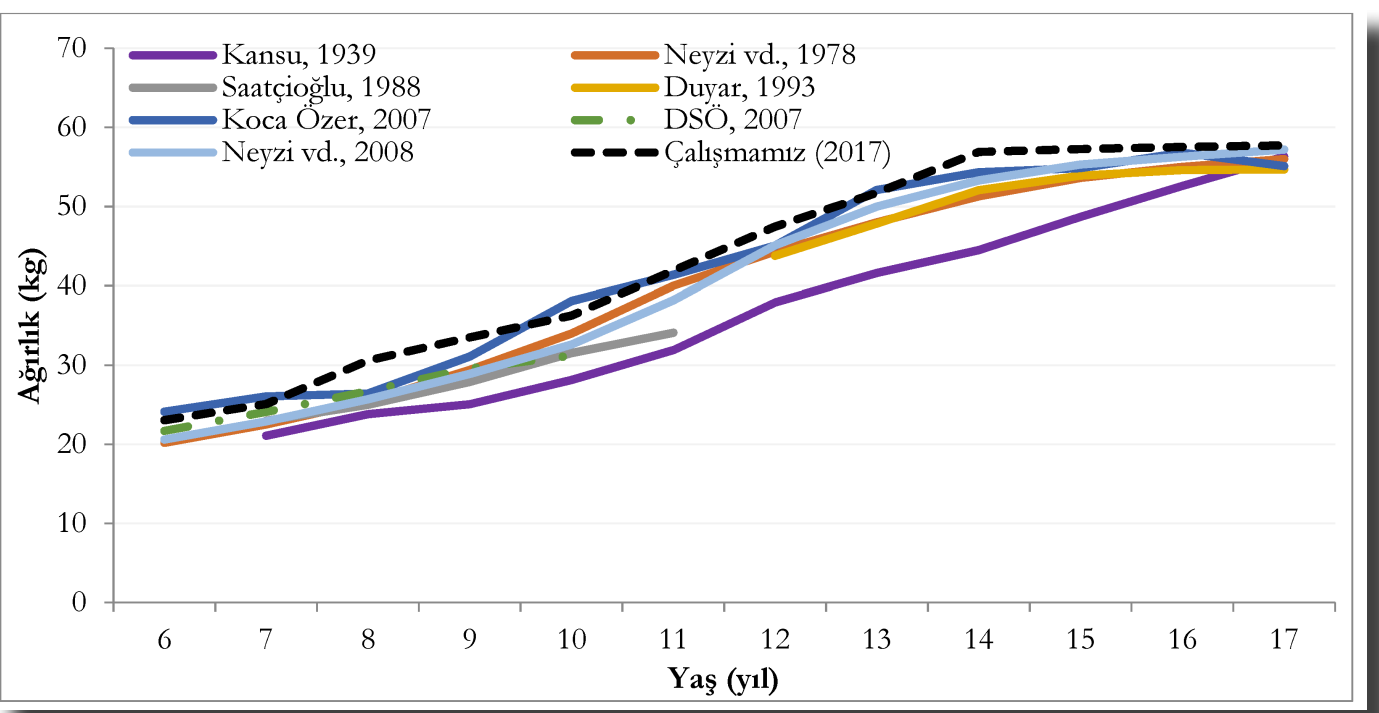

Grafik 4. Kız çocuklarında yaşlara göre ağırlı̆̆ın yıllara göre değişimi 


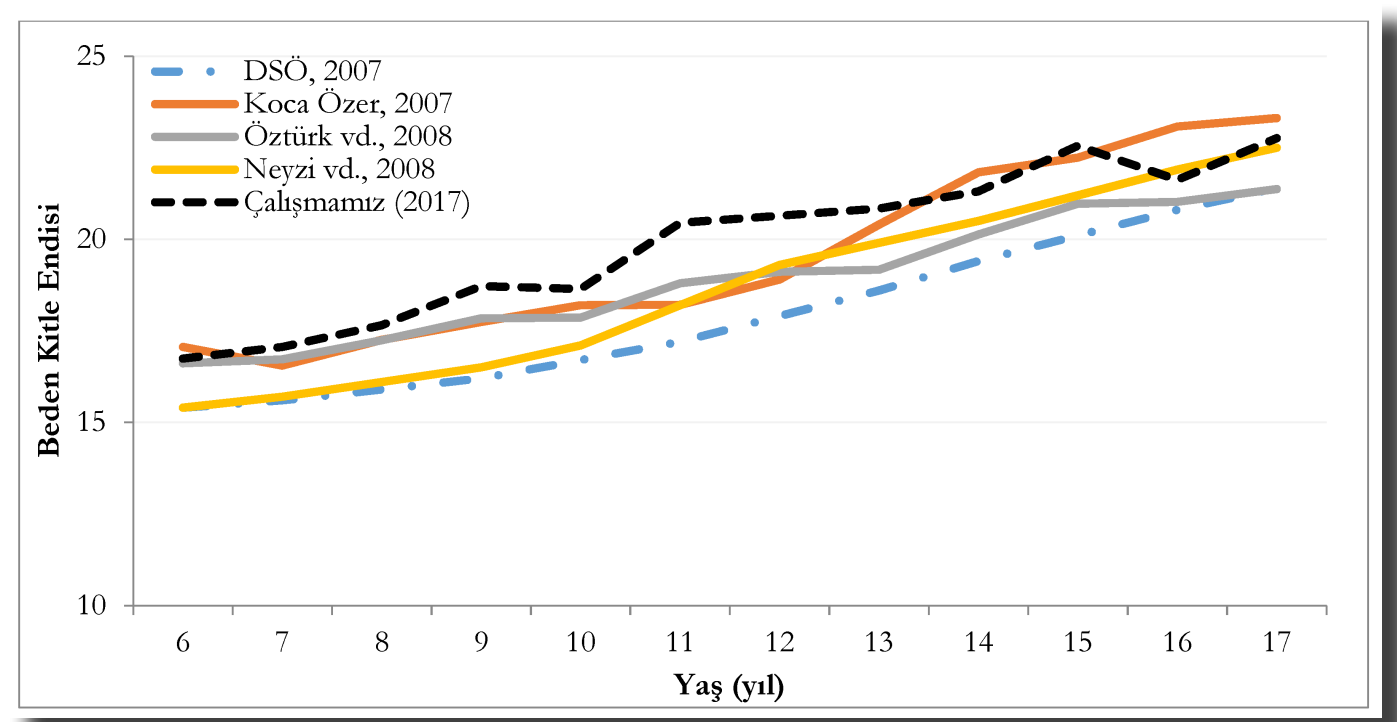

Grafik 5. Erkek çocuklarında yaşlara göre BKE’nin yıllara göre değişimi

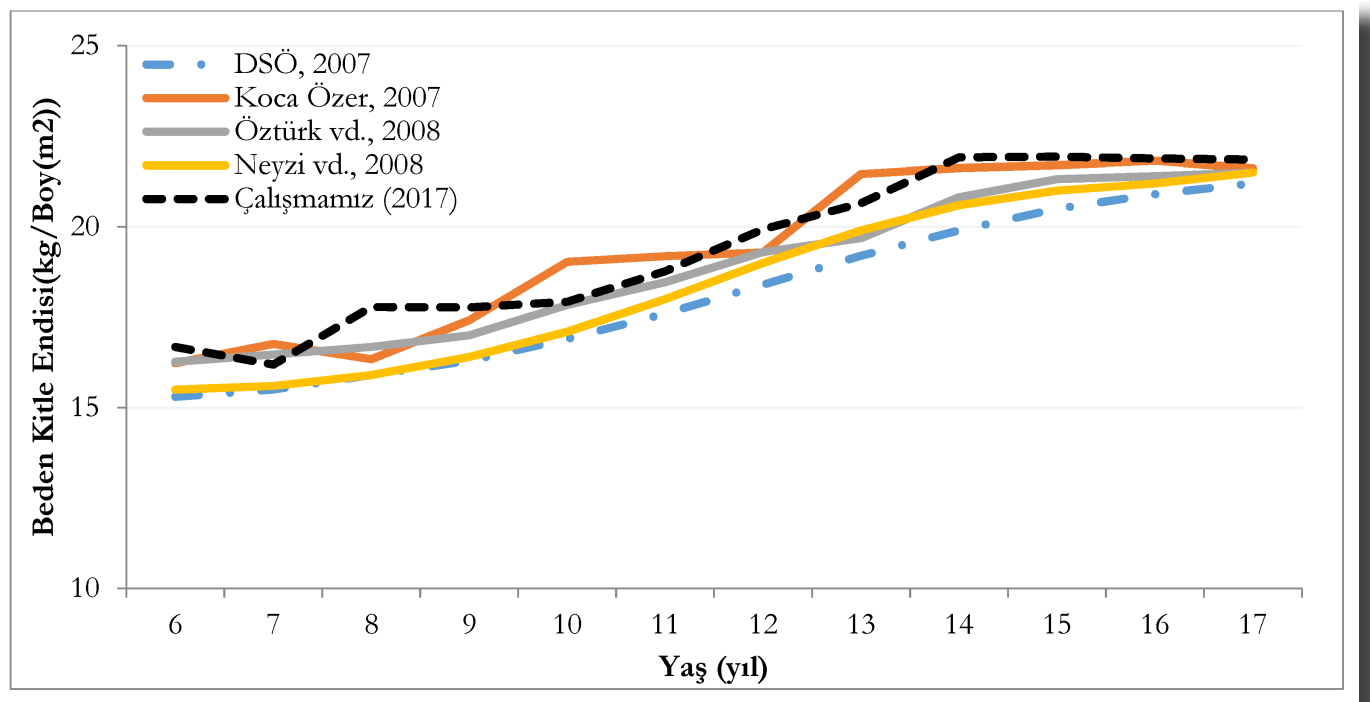

Grafik 6. Kız çocuklarında yaşlara göre BKE’nin yıllara göre değişimi

ülkede aynı anda bulunabilen iki olgudur (DSÖ, 2016). Ülkemizde, çocuklarda malnütrisyon ve obezite prevalansını ortaya koyabilmek amacıyla Sağlık Bakanlığı tarafindan Türkiye'de Okul Çağı (6-10 Yaş Grubu) Çocuklarında Büyümenin İzlenmesi (TOÇBİ) Projesi gerçekleştirilmiştir. Yapılan bu çalışmanın sonuçlanına göre çocukların \%1,3’inin çok zayıf, \%7,9'unun zayıf olduğu belirlenmiştir. TBSA'nın 6-18 yaş aralığındaki 2248 çocuk üzerinde yürüttüğü bir başka çalışmada çocukların \%3,9'unun çok zayıf, \%14,9'unun zayıf olduğu sonucuna ulaşılmıştır (TBSA, 2014). Yngve ve arkadaşları (2007) tarafindan 9 Avrupa ülkesinde 11 yaşındaki çocuklar üzerine yapılan çalışmada zayıflık oranına balkıdığında ise en yüksek oranın Belçika'da olduğu belirtilmiştir. Belçikalı kızlarda zayıflık oranı $\% 12,3$ olarak bulunurken erkeklerde ise bu oran \%11'dir (Yngve ve ark., 2007). Çalışmamız verileri ile karşılaştırıldığında, 11 yaşındaki erkek çocuklarda zayıf birey bulunmazken, kızlarda zayıllık oran $1 \% 5,8$ 'dir.
Obezite dünyanın farklı bölgelerinde giderek artan bir sorun olarak karşımıza çıkmaktadır. Gelişmekte olan ülkelerde fazla kilolu olma durumu $\% 5$ in üzerindedir ve bu durum tüm dünya için dikkatle ele alınması gereken bir sorundur. Erken çocuklukta fazla kilolu olmanın çocukluk döneminde ve erişkinlikte obeziteye neden olabileceğine vurgu yapılmaktadır. Bu durum erişkinlikte mortalite ve mordibite riskini arttırmaktadır. Dünya çapında bakıldığında, gelişmiş ülkelerde çocukluk obezitesi, gelişmekte olan ülkelere göre daha ciddi bir sağlık sorunu olarak görülmektedir. DSÖ verilerine göre çocuklarda fazla kiloluluk ve obezite prevalansı 2010 yllinda \%6,7'ye olarak bulunurken, 2020 yllinda ise dünya üzerindeki okul çocuklarının yaklaşık \%10'unun fazla kilolu, \%25’inin ise obez olacağ1 düşünülmektedir (de Onis vd., 2011).

Son yüz yıllık dönemde ülkemizdeki büyüme ve gelişme çalışmalarına bakıldığında erkek ve kız çocuklarının ağırlıklarındaki artış oldukça dikkat 
çekicidir (Kansu, 1939; Neyzi vd., 1978; Saatçioğlu, 1988; Duyar, 1993; DSÖ, 2007; Koca Özer, 2007; Neyzi vd., 2008) (Grafik 3 ve 4). Ağırlık değerlerinin kısa süreler içerisindeki artışı da dikkat çekicidir. Ağırlık artışının izlenmesi ve buna yönelik önlemlerin alınması önem taşımaktadır. Çalışmamız sonuçlarından elde edilen veriler doğrultusunda sosyo-politik süreçlerden etkilenerek değişen yaşam koşulları ve beslenme örüntüsünün uzun ya da kısa vadede ağırlık üzerinde etkili olabileceği düşünülmektedir.

BKE, obezite ve malnütrisyonun belirlenmesinde kullanılmaktadır. Ülkemizde, Sağlık Bakanlığı tarafindan Türkiye'de Okul Çağı (6-10 Yaş Grubu) Çocuklarında Büyümenin İzlenmesi (TOÇBİ) Projesi kapsamında elde edilen BKE sonuçlarına göre çocukların \%14,3’ü fazla kilolu ve \%6,5'i obez olarak belirlenmiştir (TOÇBİ, 2014). TBSA’nın 6-18 yaş arası 2248 çocuk üzerine gerçekleştirdiği çalışmada ise çocukların \%14,3'ünün fazla kilolu ve \%8,2'sinin obez olduğu belirtilmiştir (TBSA, 2014).

Neyzi ve arkadaşları tarafindan İstanbul'da 0-18 yaş arası çocuklar üzerine yapılan çalışmada, BKE değerleri çalışmamız değerleri ile karşılaştırılmış ve çalışmamız BKE değerlerinin daha yüksek olduğu görülmüştür (Neyzi vd., 2008). Koca Özer (2007) tarafindan yapılan çalışmada ise erkek çocuklarda 11 yaş dişında değerlerimizin nispeten benzer olduğu görülmektedir. Öztürk ve arkadaşları tarafından Kayseri'de yapılan çalışmadan elde edilen BKE değerleri ile çalışma değerlerimiz karşılaştırıldığında ise çalışma değerlerimizin daha yüksek olduğu görülmektedir (Öztürk vd., 2008) (Grafik 5 ve 6).

DSÖ (2007), BKE değerleri ile örneklemimize dahil edilen çocukların BKE değerlerine bakıldığında ise çalışma verilerimizin yüksekliği dikkat çekmektedir (Grafik 5 ve 6). Çalışmamız BKE değerlerinin yüksek olması, artan ağırlık ile yakın ilişki içerisindedir.

Ülkemizde obezite ve malnütrisyonun değerlendirilmesine yönelik olarak yapılan çeşitli çalışmalarda da ağırlık artışına dikkat çekilmiştir. Duyar (1993), üst sosyoekonomik düzeye dahil edilen 12-17 yaş aras1 $600 \mathrm{k} 1 \mathrm{z}$ ve 600 erkek çocuk üzerine yaptığ1 çalışmada BKE değerlerini Amerikalı yaşıt çocuklarla karşılaştırdığında ülkemizdeki kız çocuklarının Amerika'daki yaşıtlarına göre daha zayıf olduklarını belirtmiştir. Öner ve arkadaşları (2004) tarafindan 12-17 yaş arası 989 çocuk üzerine yapılan çalışmada kızların \%10,6's1 fazla kilolu, \% 2,1'i obez olarak bulunmuștur. Erkeklerin \% 11,3'ünün fazla kilolu, \% 1,6'sının ise obez oldukları belirtilmiştir. Şimşek ve arkadaşları (2005), Ankara ilindeki 6-17 yaş aras1 1510 çocuğun obezite prevelansını değerlendirdikleri çalışmalarında 6-12 yaş arası çocukların \% 4,4'ü ve 12-17 yaş aralığındaki adölesanların \% 5,4’ü obez olarak belirlemişlerdir. Koca Özer ve Gültekin (2009), çocuk ve adölesanların fazla kiloluluk ve obezite prevelansını saptamışlardır. Yuca ve arkadaşları tarafından 6-18 yaş arası 9048 çocuk üzerine yapılan çalışmada, fazla kiloluluk oranı \%11,2, obezite oraniise \%2,2 olarak bulunmuştur (Yuca vd., 2010). Fredriks (2005), yaptı̆̆1 çalışmasında Türk çocuk ve adölesanlarında fazla kiloluluk ve obezite oranlarının endişe verici olduğuna ve bu durumun erişkinlikteki fazla kiloluluk ve obezite ile ilişkilendirilebileceğine dikkat çekmiştir. Bunun yanında, TBSA çalışma verilerine göre erişkinlerde fazla kilolu olma ve obezite oranlarının geçmiş yıllara oranla artış gösterdiğine vurgu yapilmaktadir (TBSA, 2014).

Literatüre bakıldığında, özellikle gelişmekte olan ülkelerde çocukların yetersiz kalori alımının beraberinde malnütrisyona sebep olduğu aynı zamanda bu durumun boy uzunluğu üzerine de etki ettiğine vurgu yapılmaktadır. Bunun yanında gereğinden fazla kalori alımının neden olduğu obezitenin takibinin yapılması da önem taşımaktadır. Obezite ilerleyen yaşlarda kardiyovasküler hastalıkların da arasında olduğu çeşitli hastalıklara neden olabilmektedir. Çocukluk dönemindeki maruz kaldığ koşulların bireyin erişkinlik yaşamı üzerine etki ettiği belirtilmektedir (Tutkuviene, 2007; Pirgon ve Dündar, 2016).

\section{Sonuç}

Çalışmamız sonucunda ağırlık ve boy değerlerinin yaşla beraber her iki cinsiyette de artış gösterdiği görülmüştür. Buna ek olarak erkek çocuklarda değerlerin k1z çocuklardan daha yüksek olduğu görülmüştür. Çalışmamız ve ülkemizde yapılan diğer çalışmalardan elde edilen veriler değerlendirildiğinde genel olarak erkek çocuklarının çevresel şartlardan daha fazla etkilendikleri ve obezite ile malnütrisyon yüzdelerinin kızlardan daha yüksek olduğu görülmektedir. Özellikle son yıllarda her iki cinsiyette de görülen ağırlık artışı dikkat çekmektedir. $\mathrm{Bu}$ durumun ortaya çıkışında gelişen çevresel ve sosyal koşulların etlisi olduğu düşünülmektedir. Çocuklarda büyümenin takibinin yapılması ile büyümedeki herhangi bir aksaklik durumunun engellenebilmesine yönelik önlemlerin alınabilmesi mümkün olabilecektir. Büyük ölçekli antropometrik çalışmalar özellikle halk sağlı̆̆ının değerlendirilebilmesi açısından önem taşımaktadır. $\mathrm{Bu}$ nedenle ilerleyen dönemlerde yapılacak olan antropometrik çalışmaların desteklenmesi gerektiği kanisindayı.

\section{Teşekkür}

Araştırma, Ankara Üniversitesi Bilimsel Araştırma Projeleri Koordinatörlügüunün desteğiyle 16B0649002 sayılı proje kapsamında gerçekleştirilmiştir. 


\section{Kaynakça}

Bostanc1, E. Y. (1954). A research on the growth of stature of Turkish schoolchildren in Ankara. Ankara Üniversitesi Dil ve Tarih-Coğrafya Fakültesi Dergisi, 12(1-2), 41-75. https://doi. org/10.1501/Dtcfder 0000001066

Cole, T. J. (1990). The LMS method for constructing normalized growth standards. European Journal of Clinical Nutrition, 44(1), 45-60. https://gsajournals.org/articles/000/001/000001708the-lms-method-for-constructing-normalized-growthstandards.php

Cole, T. J., ve Green, P. J. (1992). Smoothing reference centile curves: the LMS method and penalized likelihood. Statistics in Medicine, 11(10), 1305-19. https://doi.org/10.1002/sim.4780111005

Cole, T. J. (2013). Growth references and growth charts. M. Hermanussen (Ed.) içinde, Auxology: Studying buman growth and development (s. 5-7). Scwheizerbart Science Publisher.

de Onis, M., Blössner, M., ve Borghi, E. (2011). Prevalence and trends of stunting among pre-school children, 19902020. Public Health Nutrition, 15(1), 142-148. https://doi. org/10.1017/S1368980011001315

Duyar, İ. (1993). Ergenlik Çağında Şişmanlık: Üst sosyoekonomik düzeyde yer alan çocuklarüzerinde antropometrik bir araştırma. Ankara Üniversitesi Dil ve Tarih Coğrafya Fakültesi Dergisi, 36(12), 79-88. https://doi.org/10.1501/Dtcfder 0000000907

Fredriks, A. M., van Buuren, S., Jeurissen, S. E. R, Dekker, F. W., Verloove-Vanhorick, S. P., ve Wit, J.M. (2003). Height, weight, body mass index, and pubertal development references for children of Turkish origin in the Netherlands. European Journal of Pediatrics, (162), 788-793. https://doi.org/10.1007/s00431003-1292-x

Fredriks, A. M., van Buuren, S., Hirasing, R. A., Wit, J.M., ve VerlooveVanhorick, S. P. (2005). Alarming prevalences of overweight and obesity for children of Turkish, Moroccan, and Dutch origin, according to the international Standard. Acta Padiatrica, 94(4), 496-498. https://doi.org/10.1111/j.1651-2227.2005. tb01923.x

Gökçay, G., Furman, A., ve Neyzi, O. (2008). Updated growth curves for Turkish children aged 15 days to 60 months. Child: Care, Health and Development, 34(4), 454-463. https://doi. org/10.1111/j.1365-2214.2008.00813.x

Hermanussen, M. (2013). Final height. M. Hermanussen (Ed.) içinde, Auxology: Studying buman growth and development (s. 7475). Scwheizerbart Science Publisher.

Kansu, Ş. A. (1939). Kız ve erkek Türk çocukları üzerinde antropometrik araştırmalar. Belleten, 9(3), 69-80. https://drive. google.com/file/d/0B7liBn5XLsAfOERwYVFoYUEzUzQ

Koca Özer, B. (2007). Growth reference centiles and secular changes in Turkish children and adolescents. Economics and Human Biology, 5(2), 280-301. https://doi.org/10.1016/j. ehb.2007.03.007

Koca Özer, B., ve Gültekin, T. (2009). Prevalence and trends in overweight and obesity among turkish children and adolescents. R. Sinha ve S. Kapoor (Ed.) içinde, Obesity: $A$ multidimensional approach to contemporary global issue (s. 106-117).
Dhanraj Book House.

Malina, R. M., ve Bourchard, C. (1991). Growth, maturation, and physical activity. Human Kinetics Publishers, Inc.

Neyzi, O., Saka, H. N., ve Kurtoğlu, S. (2013). Anthropometric studies on Turkish population - A historical review. Journal of Clinical Research in Pediatric Endocrinology, 5(1), 1-12. https:// doi.org/10.4274/Jcrpe.957

Neyzi, O., Günöz, H., Furman, A., Bundak, R., Gökçay, G., Darendeliler, F., ve Baş, F. (2008). Türk çocuklarında vücut ağırlı̆̆1, boy uzunluğu, baş çevresi ve vücut kitle indeksi referans değerleri. Cocuk Sağh̆̆ğ ve Hastalılar Dergisi, (51), 1-14.

Neyzi, O., Binyıldız, P., ve Alp, H. (1978). Türk çocuklarında büyüme gelişme normları I. Tartı ve boy değerleri. İstanbul Üniversitesi İstanbul Tip Fakültesi Mecmuası, 41(Ek 74), 1-22.

Önal, S., Özdemir, A. Meşe, C., ve Koca Özer, B. (2016). Okulöncesi dönem çocuklarda malnütrisyon ve obezite prevelansının değerlendirilmesi: Ankara örneği. Dil ve Tarih-Coğrafya Fakültesi Dergisi, 56(1), 210-225. https://doi.org/10.1501/ Dtcfder 0000001471

Öner, N., Vatansever, Ü., Sarı, A., Ekuklu, G., Güzel, A., Karasalihoğlu, S., ve Boris, N.W. (2004). Prevalence of underweight, overweight and obesity in Turkish adolescents. Swiss Medical Weekly, 134(35-36), 529-533. https://doi. org/10.4414/smw.2004.10740

Öztürk, A., Borlu, A., Çiçek, B., Altunay, C., Ünalan, D., Horoz, D., Balcı, E., Üstünbaş, H. B., Mazıcıoğlu, M. M., Hatipoğlu, N., Kurtoğlu, S., Kesim, S., ve Şenol, V. (2011). 0-18 yaş çocuk ve adölesanlarda büyüme eğrileri. Türk Aile Hekimliği Dergisi, 15(3), 112-129. https://doi.org/10.2399/tahd.11.112

Öztürk A., Mazıcıoğlu, M. M., Hatipoğlu, N., Budak, N., Keskin, G., Yazlak, Z., Balcı, N., Yıldız, H., Yıldız, K., Üstünbaş, H.B., ve Kurtoğlu, S. (2008). Reference body mass index curves for Turkish Children 6 to 18 years of age. Journal of Pediatric Endocrinology and Metabolism, 21(9), 827-36. https:// doi.org/10.1515/JPEM.2008.21.9.827

Pala, K., Aytekin, N., Akış, N., Aytekin, H., Aksu, H., ve Avcı, K. (2002). Gemlik bölgesinde 6-12 yaş çocukların ortalama ağırlık ve ortalama boylarının karşılaştırılması. Uludağ Üniversitesi Tip Fakültesi Dergisi, 28(3), 89-93. https://dergipark.org.tr/en/ download/article-file/420316

Pirgon, Ö., Bumin, N. B. (2016). Adölesan dönemde büyüme bozuklukları. Y. K. Haspolat (Ed.) içinde, Adölesanda büyüme ve puberte. Cinus Yayınları.

Saatçioğlu, A. (1988). Growth standards for 7 to 11-year-old Turkish children. Publications of the University of Kuopio.

Şimşek, F., Ulukol, B., Berberoğlu, M., Başkan Gülnar, S., Adıyaman, P., ve Öcal, G. (2005). Ankara'da bir ilköğretim okulu ve lisede obezite sıklı̆̆1. Ankara Üniversitesi T⿰р Fakültesi Mecmuası, 58(4), 163-166. https://doi.org/10.1501/Tipfak 0000000166

Tutkuviene, J. (2007). Body mass index, prevalence of overweight and obesity in Lithuanian children and adolescents, 19852002. Collegium Antropologicum, 31(1), 109-121. https:// hrcak. srce.hr/27329 
Türkiye Beslenme ve Sağlık Araştırması (TBSA). (2014). Türkiye beslenme ve sağhk araştırması 2010: Beslenme durumu ve alıskanlıklarmın değerlendirilmesi sonuc raporu. Sağlık Bakanlı̆̆1 Sağlık Araştırmaları Genel Müdürlüğü, Hacettepe Üniversitesi Sağlık Bilimleri Fakültesi Beslenme ve Diyetetik Bölümü, Ankara Numune Eğitim ve Araştırma Hastanesi. Ankara: Sağlık Bakanlığ1 Yayın No: 931. http://www.sagem.gov.tr/ TBSA Beslenme Yayini.pdf

TOÇBİ. (2011). Türkiye'de okul çağı (6-10 yas grubu) çocuklarnda büyümenin izlenmesi (TOCBI) projesi arastırma raporu. Sağllk Bakanlığı, Temel Sağlık Hizmetleri Genel Müdürlüğü, Hacettepe Üniversitesi Sağlık Bilimleri Fakültesi Beslenme ve Diyetetik Bölümü, Milli Eğitim Bakanlığı. Ankara: Sağlık Bakanlığı Yayın No: 834. http:/ / www.istanbulsaglik.gov.tr/w/ sb/halksag/belge/mevzuat/turkiye okul cocuk 6 10yas buyume izlen rap.pdf

Weiner, J., ve Lourie, J. A. (1969). Human biology: A guide to field methods (IBP bandbook, no. 9). Blackwell Scientific.

Dünya Sağlık Örgütü (DSÖ). 2007. https://www.who.int/ growthref/en/

Dünya Sağlık Örgütü (DSÖ). 2016. http://www.who.int/ nutgrowthdb/estimates2014/en/

Dünya Sağl1k Örgütü (DSÖ). 2020. https://www.who.int/ childgrowth/standards/en/

Wijnhoven, T.M., van Raaij, J.M., Spinelli, A., Starc, G., Hassapidou, M., Spiroski, I., Rutter, H, Martos, É., Rito, A.I., Hovengen, R., Pérez-Farinós, N., Petrauskiene, A., Eldin, N, Braeckevelt, L., Pudule, I., Kunešová, M., ve Breda, J. (2014). WHO European childhood obesity surveillance initiative: Body mass index and level of overweight among 6-9-year-old children from school year 2007/2008 to school year 2009/2010. BMC Public Health, (14), 806. https://doi.org/10.1186/1471-2458-14-806

Yngve, A., de Bourdeaudhuij, I., Wolf, A., Grjibovski, A., Brug, J., Due, P., Ehrenblad, B., Elmadfa, I., Franchini, B, Klepp, K-I., Poortvliet, E., Rasmussen, M., Thorsdottir, I., ve Perez Rodrigo, C. (2007). Differences in prevalence of overweight and stunting in 11-year olds across Europe: The pro children study. European Journal of Public Health, 18(2), 126-130. https:// doi.org/10.1093/eurpub/ckm099

Yuca, S. A., Yılmaz C., Cesur, Y., Doğan M., Kaya, A., ve Başaranoğlu, M. (2010). Prevalence of overweight and obesity in children and adolescents in eastern Turkey. Journal of Clinical Research in Pediatric Endocrinology, 2(4), 159-163. https://doi. org/10.4274/jcrpe.v2i4.159

\section{(c) $(1)(9)$}

2020. Telif hakları yazar(lar)a aittir.

Bu makale Creative Commons Atıf-GayriTicari 4.0 Uluslararası (CC BY-NC 4.0) lisansının hüküm ve şartları altında yayımlanan açık erişimli bir makaledir. 